\title{
Reenvisioning Family Medicine Residency Education
}

Warren P. Newton, MD, MPH; Karen Mitchell, MD

(Fam Med. 2021;53(7):487-9.)

doi: 10.22454/FamMed.2021.459102

Published Online First June 21, 2021

E ighteen months ago, family medicine set out to reenvision its residency education. The seven academic and clinical organizations defined key questions and then used these questions to frame focus groups, surveys, and commissioned papers leading to a national summit on December 6-7, 2020. All in all, over 3,500 people participated in the process and a permanent website curates the products. ${ }^{1}$ The papers in this issue are the products of the process. They are diverse and passionate, like the specialty and the people who created them, but what are the big messages going forward?

\section{The Time Is Now}

The increasing gap in health outcomes between the United States and comparable countries $^{2}$ is a wake-up call, as are reduction in life expectancy $^{3}$ and rediscovery ${ }^{4}$ of shameful disparities of health outcomes across race, ethnicity, and class. More broadly, these trends represent the coming of the end of an age in which technical advances from antibiotics through the first steps of genomics have led to dramatic improvement in health but now are increasingly limited by a health care system that provides poor access, is deeply disintegrated and unable to address cost, quality, or many aspects of patient experience. The COVID-19 pandemic has taught us this again. Reform is needed.

The recently published National Academies of Science, Engineering and Medicine report, Implementing High Value Primary Care, ${ }^{5}$ lights the way. The first National Academies study on primary care in 25 years, the report underscores that primary care is a public good and the foundation of health care. The report argues for access to primary care for everyone, training primary care teams where people live and work, and establishing governmental and financial accountability for the largest health care platform in the United States. Reform is needed.

A good place to start is residency education, and the Accreditation Council for Graduate Medical Education (ACGME) major revision of residency standards in family medicine provides an opportunity. A distinguishing feature of the US health care system is the close relationship between residency accreditation and board certification. We have been the envy of the world, and the development of residency education has been a major driver of the progress we have made since the passage of Medicare and governmental funding of residencies. But the ongoing development of that system, with its bias toward subspecialization and incomplete response to the needs of society has become part of the problem.

Family medicine can play an important role in achieving the needed reforms. The specialty is a child of the social protest of the 1960s. It developed the largest and most widely-distributed group of community-based personal physicians, insisted on recertification throughout a career and ongoing chart audits, brought residency education out of the hospital and included educational objectives, behavioral health, and practice management. Family medicine made a difference in the 1960s. We have an opportunity to do so again.

From the American Board of Family Medicine, and the University of North Carolina School of Medicine, Department of Family Medicine (Dr Newton); and the American Academy of Family Physicians, Division of Medical Education (Dr Mitchell). 


\section{Education Matters}

It is important to underscore the importance of education. In an age in which information technology has become both ubiquitous and a dominant financial driver of our economy, it is perhaps understandable that education is often likened to downloading a file. But true education in clinical care is much more than information transfer. It is about variety and volume of the right kinds of clinical experience and assessments, the development of clinical judgement and continuity of teachers and teaching. It requires skilled faculty, and coproduction by learners and patients. It also takes time.

Residency is the right initial target for medical education reform. Residency is when MDs and DOs become doctors. Residency matters. Residents learn by doing, and what they learn by doing, they continue to do for at least 20 years. The evidence is mounting that rates of operations and complications, use of medications and the cost-effectiveness of care and location of practice are imprinted in residency practice. ${ }^{6}$ If we are serious about improving the health care system, if we want to address the quadruple aim, we must begin with changes in residency education.

A corollary is that the residency practice is the curriculum. A traditional view of education lays out curricular objectives and goals. These are important but not sufficient in the residencies we hope to develop. Part of the challenge is that we need to focus on what is learned rather than what is taught. More importantly, however, we need to understand that residency is much more than knowledge transfer and technical skills. Most important are decision making, judgment, and the professionalism to lean into and respond over time to patient and community needs. And it is in the practicetaking care of patients over time in continuity practice, in hospitals and in many other settings - that critical attitudes and habits are developed. High standards for processes and outcomes in all resident practice settings are therefore foundational.

Should we train new kinds of doctors who can help lead change in health care, or change health care to nurture the development of the right kind of doctors? Our answer is yes; we need to do both. Like many, the authors represented in this special issue have worked hard and with many partners to both ends. Now the need for change is urgent and will take a long time to fulfill. So, we must work on both fronts. This is both the challenge and the opportunity for all residency faculty and program directors.

\section{Evolution or Revolution?}

Do the ideas for changes in residency education in this issue constitute evolution or revolution? Of course, the papers are diverse and passionate; it will take further dialogue, innovation, and time to implement change. Asserting firstcontact care, continuity, comprehensiveness, and coordination of care as the foundation of family medicine education ${ }^{7}$ and maintaining a broad scope of practice harken of our roots in general practice; taken seriously, they suggest a strategy of evolution. On the other hand, making the practice the curriculum, ${ }^{8}$ putting patients at the center of the residency, ${ }^{9}$ making residencies more accountable to their communities, ${ }^{10,11}$ and asking sponsoring institutions to support more robust residency education ${ }^{12}$ and care constitute a dramatic change in the directions and intent of family medicine residency education. We hope that these curricular foci will be augmented by implementation of competency-based assessment, ${ }^{13-16}$ needed reform of didactic curriculum, ${ }^{17}$ and reforms in our national system of graduate medical education. ${ }^{18,19}$ Taken together, and with the changes in payment and regulation called for by 400,000 physicians, ${ }^{20}$ they can help usher in a new direction for health care. We seek a new paradigm of care-and residency education. ${ }^{21}$

How medical students respond will also be important. In recent months, there has again been dialogue about the tension between quantity and quality of medical students going into family medicine. The goal set by Family Medicine for America's Health-that 25\% of American medical students will go into family medicine - is aspirational, and others have questioned both the feasibility and the wisdom of setting such a goal, ${ }^{22}$ emphasizing instead the quality of people going into family medicine. ${ }^{23}$ We believe both are important. Transformation of health care in the United States will not happen unless there are more family physicians (as well as other members of primary care team)_but that expansion, as well as change in health care, does not happen unless the best and brightest in every medical school class go into family medicine. Best and brightest means looking like our patients, in terms of diversity of race and gender, but also ability, organization, work ethic, and above all the commitment to service to patients and communities. We seek medical students who can go into any residency they choose. We also believe that innovations and outreach to communities by residencies will increase interest in family medicine. The role our residency directors and faculty play will be critical. 
The spotlight now turns to the ACGME Review Committee for Family Medicine which writes the residency standards. The major recommendations in these papers-the foundational role of the four Cs, a broad scope of care, the practice is the curriculum, competencybased medical education, and the need for a residency educational system more capable of both innovation and standardization, and more social accountability - are clear. By the time you read this, the ACGME writing committee will have identified the major themes of the changes and will have begun to draft the new residency standards. We encourage all readers to participate in the feedback about the new standards, and we thank you for your significant participation so far.

Beyond the immediate process of drafting new residency standards, we hope for debate and discussion within our discipline. The National Academies report ${ }^{5}$ calls for a recommitment to primary care as a public good and as the foundation of medicine and recommends sweeping changes in payment, access, community based education, health information technology, and governmental accountability. As with all major changes, it starts with us, individually, and as a specialty. Now is the future of family medicine.

CORRESPONDING AUTHOR: Address correspondence to Dr Warren P. Newton, American Board of Family Medicine, 1648 McGrathiana Pkwy, Ste 550, Lexington, KY 405111247. 859-687-2462. wnewton@theabfm.org.

\section{References}

1. Starfield Summit Re-Envisioning Family Medicine Residency Education. https://residency.starfieldsummit.com/. Published 2020. Accessed September 12, 2020.

2. National Research Council; Institute of Medicine. U.S. Health in International Perspective: Shorter Lives, Poorer Health. Woolf SH, Aron L, editors. Washington, DC: National Academies Press; 2013. https://www.ncbi.nlm.nih.gov/books/ NBK115854. Accessed May 27, 2021.

3. Woolf SH, Schoomaker H. Life expectancy and mortality rates in the United States, 1959-2017. JAMA 2019;322(20):1996-2016. doi:10.1001/jama.2019.16932

4. Institute of Medicine Committee on Understanding and Eliminating Racial and Ethnic Disparities in Health Care, Smedley BD, Stith AY, Nelson AR, eds. Unequal Treatment: Confronting Racial and Ethnic Disparities in Health Care. Washington, DC: National Academies Press; 2003. https:// www.ncbi.nlm.nih.gov/books/NBK220358/. Accessed May 28, 2021.

5. National Academies of Sciences, Engineering, and Medicine 2021. Implementing High-Quality Primary Care: Rebuilding the Foundation of Health Care. Washington, DC: The National Academies Press; 2021. doi:10.17226/25983.

6. Phillips RL Jr, Holmboe ES, Bazemore AW, George BC. Purposeful imprinting in graduate medical education: opportunities for partnership. Fam Med. 2021;53(7):574-577.
7. Bazemore A. Sailing the 7Cs: Starfield revisited as a foundation of family medicine residency redesign. Fam Med. 2021; 53(7):506-489

8. Neutze D, Hodge B, Steinbacher E, Carter C, Donahue KE, Carek PJ. The Practice is the curriculum. Fam Med. 2021;53(7): 567-573. doi:10.22454/FamMed.2021.154874

9. Lehmann C, Liao W. The patient voice: participation and engagement in family medicine practice and residency education. Fam Med. 2021;53(7):578-579. doi:10.22454/ FamMed.2021.327569

10. Carek P. Ongoing self-review and continuous quality improvement among family medicine residencies. Fam Med. 2021;53(7):626-631.

11. Wheat SJG. Community: the heart of family medicine. Fam Med. 2021;53(7):528-530.

12. Kaufman A. Social accountability and graduate medical education. Fam Med. 2021;53(7):632-637.

13. Holmboe ES. The transformational path ahead: competencybased medical education in family medicine. Fam Med. 2021;53(7):583-589. doi:10.22454/FamMed.2021.296914

14. Saultz J. Competency-based education in family medicine residency education. Fam Med. 2021;53(7):590-592. doi:10.22454/FamMed.2021.816448

15. Fowler N, Lemire F, Oandasan I, Wyman R. The evolution of residency training in family medicine: a Canadian perspective. Fam Med. 2021;595-598. doi:10.22454/ FamMed.2021.718541

16. Newton WP, Magill MK. What family medicine can learn from other specialties. Fam Med. 2021;606-607. doi:10.22454/ FamMed.2021.976389

17. Zakrajsek T, Newton WP. Promoting active learning in residency didactic sessions. Fam Med. 2021;608-610. doi:10.22454/FamMed.2021.894932

18. Carney PA, Ericson A, Conry CM, et al. Financial considerations associated with a fourth year of residency training in family medicine: findings from the Length of Training Pilot Study. Fam Med. 2021;53(4):256-266. doi:10.22454/ FamMed.2021.406778

19. Douglass AB, Barr WB, Skariah JM, et al. Financing the fourth year: experiences of required 4-year family medicine residency programs. Fam Med. 2021;53(3):195-199. doi:10.22454/FamMed.2021.249809

20. Stewart AD, Martin S, Goza SH, et al. Unified Voice, Unified Vision, Changing Primary Care Finance. https:// static1.squarespace.com/static/5fb2d43b0297530c833714e1/ t/5fe35a 5f0c3b8c5933a a 7122/1608735327908/ Unified+Voice+Unified+Vision+-+Open+Letter.pdf. Accessed April 14, 2021.

21. Saultz JW. Revolutionary leadership and family medicine education. Fam Med. 2008;40(4):277-280

22. David AK. Matching $25 \%$ of medical students in family medicine by 2030: realistic or beyond our reach? Fam Med. 2021;53(4):252-255. doi:10.22454/FamMed.2021.982403

23. Magill MK, Saultz J. Quality before quantity. Fam Med. 2021;53(4):249-251. doi:10.22454/FamMed.2021.156395 